\title{
Passage of stable isotope-labeled grass silage fiber and fiber-bound protein through the gastrointestinal tract of dairy cows
}

\author{
D. Warner, ${ }^{* 1}$ J. Dijkstra, ${ }^{*}$ W. H. Hendriks, ${ }^{*} \dagger$ and W. F. Pellikaan* \\ *Animal Nutrition Group, Wageningen University, PO Box 338, 6700 AH Wageningen, the Netherlands \\ †Faculty of Veterinary Medicine, Utrecht University, PO Box 80.163, 3508 TD Utrecht, the Netherlands
}

\begin{abstract}
Fractional passage rates are required to predict nutrient absorption in ruminants but data on nutrientspecific passage kinetics are largely lacking. With the use of the stable isotope ratio $(\delta)$ as an internal marker, we assessed passage kinetics of fiber and fiberbound nitrogen $(\mathrm{N})$ of intrinsically labeled grass silage from fecal and omasal excretion patterns of $\delta^{13} \mathrm{C}$ and $\delta^{15} \mathrm{~N}$. In a $6 \times 6$ Latin square, lactating dairy cows received grass silages $[455 \mathrm{~g} / \mathrm{kg}$ of total diet dry matter $(\mathrm{DM})]$ in a $2 \times 3$ factorial arrangement from ryegrass swards fertilized at low (45 kg of $\mathrm{N} / \mathrm{ha}$ ) or high (90 $\mathrm{kg}$ of $\mathrm{N} / \mathrm{ha}$ ) levels of $\mathrm{N}$ and harvested at 3 maturity stages. Feed intake $(16.7 \pm 0.48 \mathrm{~kg}$ of $\mathrm{DM} / \mathrm{d}$; mean \pm standard error of the mean) and milk yield (26.7 \pm $0.92 \mathrm{~kg} / \mathrm{d}$ ) increased at the high level of $\mathrm{N}$ fertilization and at decreasing maturity. Nutrient digestibility decreased with increasing plant maturity, particularly at the high level of $\mathrm{N}$ fertilization, essentially reflecting dietary treatment effects on the nutritional composition of the grass silage. Fractional rumen passage rates $\left(K_{1}\right)$ were highest and total mean retention time in the gastrointestinal tract (TMRT) was lowest when based on the external marker chromium mordanted fiber $(\mathrm{Cr}-$ NDF; $0.047 / \mathrm{h}$ and $38.0 \mathrm{~h}$, respectively). Fecal $\delta^{13} \mathrm{C}$ in the acid detergent fiber fraction $\left({ }^{13} \mathrm{CADF}\right)$ provided the lowest $K_{1}(0.023 / \mathrm{h})$ and the highest TMRT (61.1 h) and highest peak concentration time (PCT; $24.3 \mathrm{~h}$ ) among markers. In comparison, fecal fiber-bound $\mathrm{N}$ $\left({ }^{15} \mathrm{NADF}\right)$ had a considerably higher $K_{1}(0.032 / \mathrm{h})$ and lower TMRT (46.4 h) than ${ }^{13} \mathrm{CADF}$. Total N (measured with $\left.{ }^{15} \mathrm{NDM}\right)$ had a comparable $K_{1}(0.034 / \mathrm{h})$ to that of ${ }^{15} \mathrm{NADF}$ but provided the highest fractional passage rates from the proximal colon-cecum $\left(K_{2} ; 0.37 / \mathrm{h}\right)$ and lowest PCT $(17.4 \mathrm{~h})$ among markers. A literature review indicated unclear effects of grass silage maturity on $K_{1}$ and unknown effects of $\mathrm{N}$ fertilization on $K_{1}$. Our study indicated no effect of advancing maturity on fecal
\end{abstract}

Received June 21, 2013.

Accepted August 18, 2013.

${ }^{1}$ Corresponding author: daniel.warner@wur.nl
$K_{1}$ and a trend for $K_{1}$ to increase with the high level of $\mathrm{N}$ fertilization. Parameter $K_{2}$ increased, whereas PCT and TMRT generally decreased with the high level of $\mathrm{N}$ fertilization. Omasal digesta sampling largely confirmed results based on fecal sampling. Results indicate that the use of $\delta^{13} \mathrm{C}$ and $\delta^{15} \mathrm{~N}$ can describe fiber-specific passage kinetics of forage.

Key words: passage marker, ${ }^{13} \mathrm{C},{ }^{15} \mathrm{~N}$, perennial ryegrass

\section{INTRODUCTION}

Quantitative knowledge on fractional rumen passage rates $\left(\boldsymbol{K}_{1}\right)$ is required to determine ruminal VFA and microbial protein yields and to determine site and extent of degradation of ingested feed (Dijkstra et al., 2007). Therefore, $K_{1}$ is an essential parameter in several feed evaluation systems and mechanistic rumen models that predict absorption of nutrients in the small intestine as well as excretion of nutrients with respect to environmental and metabolic load (Kebreab et al., 2009). Fractional rumen passage rates are conventionally determined by marker techniques involving external or inert internal markers. External markers are not inherent to the feed and have, therefore, been criticized for not fully representing the passage behavior of the diet (Smith, 1989; Tamminga et al., 1989). In particular, external markers do not provide passage rates specific to feed chemical components. In principle, internal markers are preferred because they are inherent to the feed ingested by the animal; however, inert markers require time- and labor-intensive rumen evacuations to determine the rumen pool size. By labeling specific feed fractions with stable isotopes, fractional passage rates can be determined from stable isotopes as internal markers determined in feces (Svejcar et al., 1993; Südekum et al., 1995). Based on this principle, Huhtanen and Hristov (2001) determined fractional passage rates of fiber-bound nitrogen $(\mathrm{N})$ from ${ }^{15} \mathrm{~N}$-labeled alfalfa (Huhtanen and Hristov, 2001). A subsequent study has shown that the carbon isotope ratio $\left({ }^{13} \mathrm{C}:{ }^{12} \mathrm{C}\right)$; that is, $\delta^{13} \mathrm{C}$, can be used to assess fiber passage kinetics of 
a $\delta^{13} \mathrm{C}$-labeled grass silage and that the $\delta^{13} \mathrm{C}$ did not change with microbial rumen fermentation under in vitro conditions (Pellikaan et al., 2013). Disappearance of the labeled fiber fractions in the gastrointestinal tract did not, therefore, affect respective passage kinetics estimated from the $\delta^{13} \mathrm{C}$ in the apparent undigested fecal fraction. This has been validated in vivo by quantifying the carbon isotopes from feed and fecal output [L. M. M. Ferreira, University of Trás-os-Montes and Alto Douro (UTAD), Vila Real, Portugal, unpublished data] resulting in an equal $\delta^{13} \mathrm{C}$ between the isotope pool flowing into the rumen and that in feces.

In the study of Pellikaan et al. (2013), changing the diet from a low to high digestible grass silage had no effect on passage kinetics, based on 2 cows. Previous studies based on external or inert markers suggest that grass silage quality affects passage kinetics, although effects were not clear and results from literature range from slightly negative or no effects (Mambrini and Peyraud, 1994; Lamb et al., 2002; Lund et al., 2006; Kuoppala et al., 2009; Bayat et al., 2010, 2011) to clearly positive effects (Gasa et al., 1991; Bosch et al., 1992a; Rinne et al., 1997a, 2002) of advancing plant maturity on $K_{1}$. Effects of $\mathrm{N}$ fertilization were not specifically investigated with regard to passage kinetics, but results from in situ degradation studies indicate clear effects of $\mathrm{N}$ fertilization level on fractional degradation rates and the potentially rumen digestible fraction (van Vuuren et al., 1991; Valk et al., 1996; Peyraud et al., 1997). As rumen degradation of feed particles might reduce the probability of their rumen escape by increasing particle buoyancy (Sutherland, 1988), fractional rumen degradation might be indirectly related to fractional rumen passage.

Previously, we used intrinsic isotope labeling of corn silages varying in nutritional quality to assess component-specific fractional passage rates (Warner et al., 2013a). The aim of the present study was to assess feed component-specific passage kinetics of grass silage from early through late maturity from ryegrass swards fertilized at 2 different $\mathrm{N}$ levels. Ryegrass plants were uniformly labeled with $\delta^{13} \mathrm{C}$ and $\delta^{15} \mathrm{~N}$ under greenhouse conditions, and passage kinetics of fiber and fiberbound $\mathrm{N}$ were determined based on the respective $\delta$ values, determined in fecal and omasal digesta samples, and compared with the external marker Cr-NDF.

\section{MATERIALS AND METHODS}

\section{Animals and Diet}

All experimental procedures were approved by the Institutional Animal Care and Use Committee of Wageningen University (Wageningen, the Netherlands) and carried out under the Dutch Law on Animal Experimentation. Six multiparous Holstein-Friesian dairy cows in their second to fourth lactation, fitted with permanent rumen cannulas $(10 \mathrm{~cm}$ i.d., Type 1C, Bar Diamond Inc., Parma, ID), were individually housed in tiestalls. At the start of the experiment, cows were 63 $\pm 13 \mathrm{DIM}$ (mean $\pm \mathrm{SD}$ ), averaged $549 \pm 64 \mathrm{~kg}$ of BW, had an average daily feed intake of $17.2 \pm 2.60 \mathrm{~kg}$ of $\mathrm{DM}$, and produced $33.1 \pm 5.76 \mathrm{~kg}$ of milk/d. Animals were fed a TMR consisting of $455 \mathrm{~g} / \mathrm{kg}$ DM grass silage, $195 \mathrm{~g} / \mathrm{kg}$ DM corn silage, and $350 \mathrm{~g} / \mathrm{kg}$ DM compound feed (Table 1). The compound feed ingredients mainly originated from cool-season $\mathrm{C}_{3}$ plants to keep the background level of ${ }^{13} \mathrm{C}$ low and similar to that of the natural enrichment level of the grass silage mixed in the experimental diet. Grass silage was prepared from a perennial ryegrass (Lolium perenne) sward sown as a 70:30 mixture (Havera; Limagrain Nederland, Rilland, the Netherlands) of late-heading tetraploid cultivars ('Pomposo' and 'Alcander') and diploid cultivars ('Frisian 1 and 'Jalinas') on clay soil. Grass was fertilized at $2 \mathrm{~N}$ fertilization levels and harvested at 3 maturity stages (Table 1). Levels of $\mathrm{N}$ fertilization were either $45 \mathrm{~kg}$ of N/ha (N45) or $90 \mathrm{~kg}$ of N/ha (N90) per cut, applied as an N-P-K complex. Maturity stages were set to obtain a target DM yield in the range of 1,800 to $2,000 \mathrm{~kg} / \mathrm{ha}$ (early), 3,200 to $3,400 \mathrm{~kg} / \mathrm{ha}$ (mid), and 4,600 to $4,800 \mathrm{~kg} / \mathrm{ha}$ (late). The phenological development stages for the respective maturity stages were stem elongation (early maturity), begin heading (mid maturity), and full heading (late maturity). The field received $50 \mathrm{~kg}$ of $\mathrm{N} /$ ha before the first regrowth. Fresh grass from the second (mid to late maturity) and third regrowth (early maturity) was harvested from August to September 2010, wilted for $12 \mathrm{~h}$, cut to a theoretical chop length of $40 \mathrm{~mm}$, and ensiled in bales without addition of inoculants.

Grass silage treatments were randomly distributed over 6 animals and 6 experimental periods according to a Latin square design with $2 \times 3$ factorial arrangement of treatments. Each experimental period lasted $21 \mathrm{~d}$ starting with a 14-d adaptation period to the diet. From d 12 on, animals were fed $95 \%$ of the individual DMI measured during the adaptation period to minimize feed refusals during the measuring days. Animals received their daily rations in 2 equal meals at 0600 and $1700 \mathrm{~h}$. The diet was prepared twice weekly and stored in a cooling unit at $8^{\circ} \mathrm{C}$ from April onwards. Feed samples were collected each time the diet was prepared. Feed residues were collected daily before the afternoon feeding. Feed samples and residues were pooled per animal over each experimental period. Animals were milked twice daily during feeding times and milk samples were collected from d 15 through 21. Feed 
Table 1. Chemical composition of the diet consisting of grass silage at 2 nitrogen fertilization levels (45 and $90 \mathrm{~kg}$ of N/ha; N45 and N90, respectively) and harvested at early through late maturity, and of corn silage and compound feed

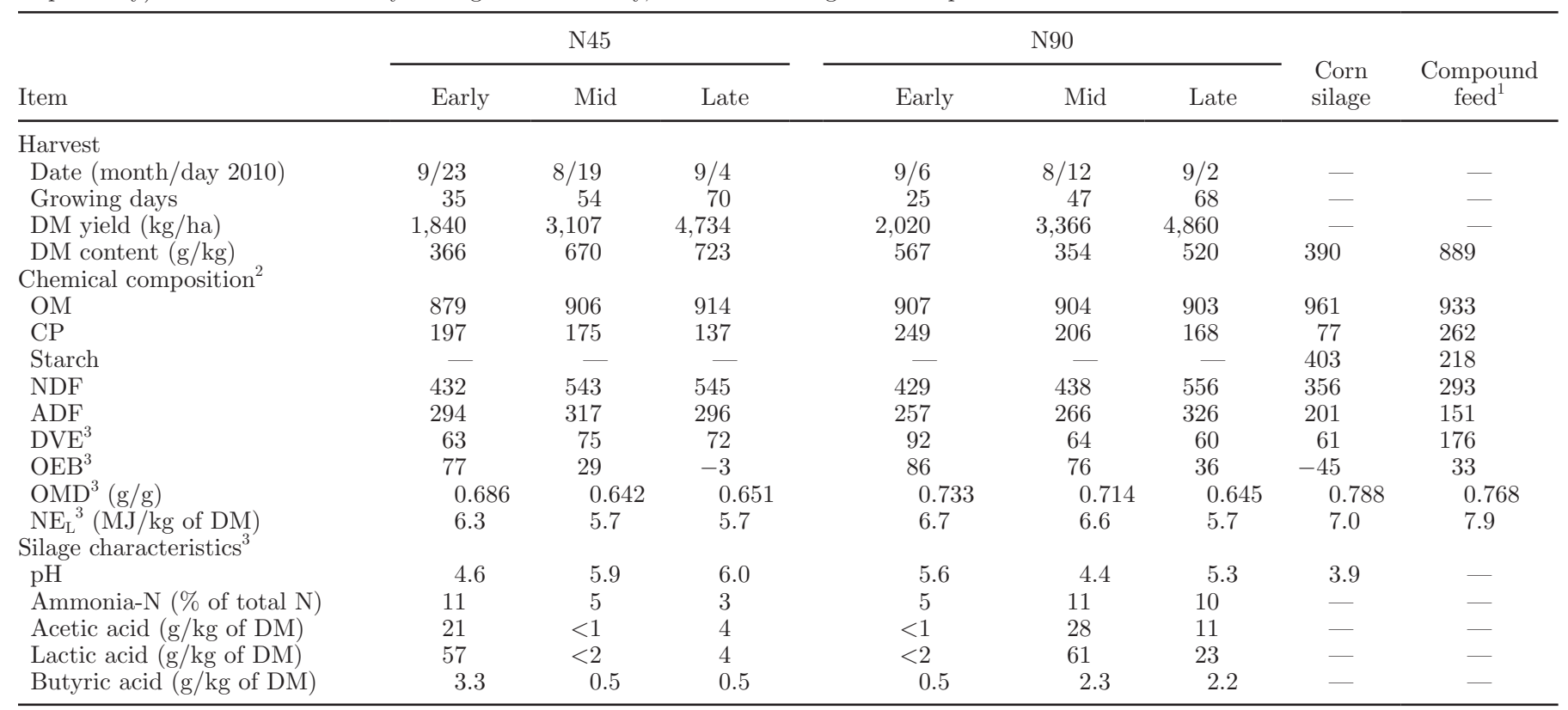

${ }^{1}$ Ingredients (g/kg of DM): wheat (80.0), sunflower seeds (140.0), soybean hulls (26.5), palm kernel expeller (90.0), soybeans (185.0), sugar beet pulp (75.0), potato starch (200.0), MervoBest rumen-protected soybean meal (185.0; Pre-Mervo, Utrecht, the Netherlands), phosphoric acid limestone (7.5), salt (3.0), mineral premix (8.0).

${ }^{2} \mathrm{NDF}=$ ash-free amylase-treated NDF; ADF = ash-free ADF $;$ DVE = intestinal digestible protein; OEB = rumen degraded protein balance; $\mathrm{OMD}=\mathrm{OM}$ digestibility. Values expressed as means $(\mathrm{g} / \mathrm{kg}$ of DM, unless specified otherwise) of 6 experimental periods (starch not determined for grass silage).

${ }^{3}$ Determined by near-infrared spectroscopy (Blgg AgroXpertus, Wageningen, the Netherlands).

intake and milk yield determined from d 15 through 21 of each experimental period were averaged per period for statistical analysis. One animal was removed from the experiment in periods 5 and 6 due to general health issues not related to the dietary treatments or experimental conditions, reducing the treatment combinations to $\mathrm{n}=34$.

\section{Markers}

Chromium-mordanted fiber (Cr-NDF) and the stable isotope ratios of carbon $\left(\delta^{13} \mathbf{C}\right)$ and nitrogen $\left(\delta^{15} \mathbf{N}\right)$ were used as external and internal passage markers, respectively. The Cr-NDF (45.9 g of $\mathrm{Cr} / \mathrm{kg}$ of $\mathrm{Cr}-\mathrm{NDF}$ ) was prepared as described by Udén et al. (1980) from wheat straw, dried and ground to pass a $0.5-\mathrm{mm}$ screen. The isotope-enriched internal markers were prepared as $\delta^{13} \mathrm{C}$ - and $\delta^{15} \mathrm{~N}$-labeled grass silage originating from the field that also provided the bulk grass silage. In brief, representative ryegrass shoots from the second regrowth were randomly collected from the field and grown on hydroponics $\left(8.6\right.$ shoots $\left./ \mathrm{m}^{2}\right)$ under climatecontrolled greenhouse conditions in hermetically sealed isotope assimilation chambers (IsoLife, Wageningen, the Netherlands), specifically designed for homogeneous atmospheric isotope-labeling (Gorissen et al., 1996). From plant emergence onwards, grass was continuously enriched under high levels of ${ }^{13} \mathrm{CO}_{2}$ and by injecting plant pots with a $\mathrm{K}^{15} \mathrm{NO}_{3}$ solution. The labeled grass plants were exposed to similar conditions to the field plants; for example, by adjusting the light schedule in the greenhouse to the field conditions, and inducing wind stress to the labeled plants. Grass plants received the identical fertilization regimen and were harvested at a similar physiological stage $(172,322$, and $498 \mathrm{~g}$ of $\mathrm{DM} / \mathrm{m}^{2}$ from early through late maturity) as the field plants. Plants were subsequently wilted, cut to size $(2 \mathrm{~cm})$, placed into several bags of larger mashed grit gauze (pore size $212 \mu \mathrm{m}$; PA-74, Sefar Nytal, Heiden, Switzerland), and distributed over silage bales to be ensiled together with the field plants over an 8-wk period. The mean degree of atom percent (atom\%) as a proportion of total $\mathrm{C}$ or $\mathrm{N}$ in the $\mathrm{DM}$ of the labeled grass silage ranged between 6.74 and 8.20 atom $\%{ }^{13} \mathrm{C}$ excess and between 16.93 and 18.11 atom $\%{ }^{15} \mathrm{~N}$ excess for the different treatments $(\mathrm{n}=6)$.

On d 15, animals received a ruminal pulse dose of corresponding isotope-labeled grass silage ( $15 \mathrm{~g}$ of DM) and Cr-NDF (100 g of DM). Pulse dosing started at $0900 \mathrm{~h}$ with cow 1 and continued after an interval of 
30 min for each consecutive animal. Before pulse dosing, the frozen and cut marker material was further cut to pieces of approximately $0.5 \mathrm{~cm}$ to resemble ingested bulk grass silage particles. From d 11 through 19, cobalt-EDTA (Udén et al., 1980) was continuously infused $(0.5 \mathrm{~L} / \mathrm{h} ; 1.14 \mathrm{~g}$ of $\mathrm{Co} / \mathrm{d}$ dissolved in $12 \mathrm{~L}$ of water) in the rumen following Faichney (1975) to measure total-tract feed digestibility (from d 15 through 19), preceded by a primer dose of 1.5 times the daily dose.

\section{Sampling and Measurements}

Feces. Directly after administration of markers into the rumen, 20 spot samples of feces were collected after defecation. Fecal samples were collected in sampling blocks of $3 \mathrm{~h}$ each at times $t=0,3,6,9,12,15,18$, $24,30,36,48,54,60,72,78,84,96,102,108$, and $120 \mathrm{~h}$ following pulse dose administration. Feces were weighed and thoroughly homogenized by hand, and a representative sample of approximately $400 \mathrm{~g}$ of fresh matter was stored at $-20^{\circ} \mathrm{C}$. An aliquot of $1 \%$ fresh feces was taken from each collection time and pooled over 1 experimental period to determine total-tract feed digestibility.

Omasal Digesta. Fifteen spot samples $(\sim 750 \mathrm{~mL})$ of omasal digesta were collected during fecal collection times by means of the omasal sampling technique after Huhtanen et al. (1997), with modifications as described in detail by Warner et al. (2013a), at average times $t$ $=0,3,5,9,12,14,17,24,30,36,47,59,71,96$, and $120 \mathrm{~h}$ after pulse dose administration. Omasal $\mathrm{pH}$ was measured immediately using an electronic $\mathrm{pH}$ meter (pH electrode HI1230, Hanna Instruments, IJsselstein, the Netherlands).

Rumen Liquid. On d 21, approximately $350 \mathrm{~mL}$ of rumen liquid was collected proportionally from a cranial, middle, and caudal direction. Per treatment and animal, a total of 4 rumen fluid samples were collected prior to bag removal for rumen degradability at times $t$ $=2,6,8$, and $10 \mathrm{~h}$ after morning feeding. Subsamples of $0.75 \mathrm{~mL}$ each were taken for VFA and ammonia $\left(\mathrm{NH}_{3}\right)$ analyses, and rumen $\mathrm{pH}$ was measured immediately. The VFA and $\mathrm{NH}_{3}$ samples were stored at $-20^{\circ} \mathrm{C}$ in $85 \%$ phosphoric acid (1:1, vol/vol) and 10\% TCA (1:1, $\mathrm{vol} / \mathrm{vol})$, respectively.

Rumen Degradability. On d 18 through 21, rumen degradation of fresh grass silage was determined in situ per individual animal and per silage type treatment in situ as described by Warner et al. (2013a). Incubations $(0,2,4,8,24,48$, and $72 \mathrm{~h})$ started with the 72 -h incubation bags according to the all-out procedure at $80 \mathrm{~h}$ after marker administration to ensure similar conditions of degradation and passage rates. Previous studies showed that fecal marker concentrations were close to baseline concentrations after $4 \mathrm{~d}$ (Warner et al., 2013b). Fractional rumen degradation rates were related to fractional rumen passage rates to test a potential relationship.

\section{Chemical Analyses}

Samples were freeze-dried and ground over a hammer mill to pass a 1-mm screen (Peppink 100 AN, Peppink, Olst, the Netherlands). Contents of DM, ash, CP, starch, NDF, and ADF were analyzed as described by Abrahamse et al. (2008a,b). Concentrations of VFA and $\mathrm{NH}_{3}$ were determined as described by Warner et al. (2013a). Milk composition was analyzed by midinfrared reflection spectroscopy (Milk Control Station VVB, Nunspeet, the Netherlands).

Fecal and omasal Co and $\mathrm{Cr}$ concentrations were determined using an atomic absorption spectrophotometer (AA240FS, Varian, Palo Alto, CA) after oxidation with wet destruction as described by Pellikaan et al. (2013). Isotopic excretion patterns in feces and omasal digesta were determined for $\delta^{13} \mathrm{C}$ and $\delta^{15} \mathrm{~N}$ in the total $\mathrm{DM}$ $\left({ }^{13} \mathrm{CDM} ;{ }^{15} \mathrm{NDM}\right)$, and for fiber-bound $\delta^{13} \mathrm{C}$ and $\delta^{15} \mathrm{~N}$ in the ADF fraction $\left({ }^{13} \mathbf{C A D F} ;{ }^{15} \mathbf{N A D F}\right)$. The ADF fraction was obtained by boiling dried and ground test samples with acid detergent in filter bags (Type F57, porosity $25 \mu \mathrm{m}$, Ankom Technology, Macedon, NY) but omitting the final combustion. The DM and ADF fractions were pulverized in a bullet mill (MM2000, Retsch, Haan, Germany) for 3 min at $85 \mathrm{~Hz}$ and analyzed for $\delta^{13} \mathrm{C}$ and $\delta^{15} \mathrm{~N}$ by elemental analysis using an isotope ratio mass spectrometer (Delta V Advantage, Thermo Scientific, Bremen Germany). The relative isotopic enrichment was expressed as $\delta^{13} \mathrm{C}$ and $\delta^{15} \mathrm{~N}$ (i.e., the respective ${ }^{13} \mathrm{C}:{ }^{12} \mathrm{C}$ and ${ }^{15} \mathrm{~N}:{ }^{14} \mathrm{~N}$ ratios) in the samples relative to the isotopic ratio of the respective international standards Vienna Pee Dee Belemnite $\left(\delta^{13} \mathrm{C}\right.$-labeled glucose as working standard) and air $\left(\delta^{15} \mathrm{~N}\right.$-labeled urea as working standard). Working standards were purchased from IVA Analysentechnik (Meerbusch, Germany). After correction for natural isotopic abundance, fecal and omasal excretion patterns of atom $\%{ }^{13} \mathrm{C}$ and ${ }^{15} \mathrm{~N}$ excess were established, and scaled to marker peak concentration to improve model fit.

\section{Curve Fitting and Statistical Analyses}

Curve-fitting procedures and statistical analyses are outlined in Warner et al. (2013a). In brief, fractional passage rates were derived from fecal and omasal excretion patterns of $\delta^{13} \mathrm{C}, \delta^{15} \mathrm{~N}$, and $\mathrm{Cr}$, fitted iteratively with a nonlinear multicompartmental model (Dhanoa et al., 1985). The multicompartmental model provided the most satisfactory curve fits for corn silage in feces and 
omasal digesta (Warner et al., 2013a), compared with 2-compartmental models with age dependency with increasing order of gamma distribution (GnG1 models; $\mathrm{n}=2$ to 5 ). The multicompartmental model assigns a slow fractional passage rate $\left(\boldsymbol{K}_{1}\right)$ to the compartment with the highest retention time (i.e., the reticulorumen) and a fast fractional passage rate $\left(\boldsymbol{K}_{2}\right)$ to the compartment with the lowest retention time (i.e., the proximal colon-cecum). With regard to omasal marker excretion, $K_{2}$ most likely represents rumen-related processes, such as mixing time and gas entrapment of marker particles, rather than a particle-retaining compartment per se (Warner et al., 2013a). Predicted marker concentrations were compared with the observed values using the root mean square prediction error, which was decomposed into errors due to overall bias of prediction, errors due to deviation of the regression slope from unity, and errors due to random variation (Bibby and Toutenburg, 1977), and scaled to the observed mean (mean prediction error, MPE). Log-transformed model parameters were tested by ANOVA in a Latin square split-plot design, with a $2 \times 3$ factorial arrangement of treatments $(2 \mathrm{~N}$ fertilization levels $\times 3$ maturity stages $)$ within main plots and type of marker assigned to subplots by mixed model procedures of SAS (version 9.2, SAS Institute, Cary, NC), as described in detail by Warner et al. (2013a). Differences between marker types were assessed using orthogonal contrasts. In situ degradation residues were fitted as described by Tas et al. (2006) using a first-order model with lag time (Robinson et al., 1986). Rumen $\mathrm{pH}, \mathrm{VFA}$, and $\mathrm{NH}_{3}$ concentrations were considered repeated measurements and were analyzed as a Latin square split-plot design with repeated measurements as the subplots effects. Animal performance data were tested by ANOVA as a Latin square with a 2 $\times 3$ factorial arrangement of treatments.

\section{RESULTS}

\section{Characteristics of the Grass Silage}

Diet. Six nutritionally contrasting grass silages differing particularly in their $\mathrm{CP}$ and NDF contents (Table 1) were fed to dairy cows. Nitrogen fertilization increased $\mathrm{CP}$ content by, on average, $38 \mathrm{~g} / \mathrm{kg}$ of DM with N90 compared with N45. Advancing grass silage maturity decreased $\mathrm{CP}$ content at an average rate of $1.8 \mathrm{~g} / \mathrm{kg}$ of DM per d from early through late maturity. The lowest absolute CP value was observed for N45 of late maturity $(137 \mathrm{~g} / \mathrm{kg}$ of DM). The NDF content increased with increasing maturity stage although differences were less clear than for CP. The NDF content of N45 was comparable between the last 2 maturity stages (mid to late), whereas that of N90 was compa- rable between the first 2 maturity stages (early to mid). Treatment N90 showed a particularly quick regrowth performance during early and mid maturity, producing respective average daily amounts of $28 \mathrm{~kg}$ and $14 \mathrm{~kg}$ of $\mathrm{DM} /$ ha more than $\mathrm{N} 45$; at late maturity, the regrowth performance was comparable between $\mathrm{N}$ fertilization levels. The concurrent increase of $\mathrm{P}$ and $\mathrm{K}$ with $\mathrm{N}$ fertilization rates as part of the N-P-K complex did not appear to change the respective concentrations among fertilization levels. Concentrations were always within recommended allowance and were (mean \pm SEM) 4.0 $\pm 0.17 \mathrm{~g}$ of $\mathrm{P} / \mathrm{kg}$ of $\mathrm{DM}$ and $26.2 \pm 0.79 \mathrm{~g}$ of $\mathrm{K} / \mathrm{kg}$ of $\mathrm{DM}$, respectively.

Animals. Animals had daily average feed intake of $16.7 \pm 0.48 \mathrm{~kg}$ of DM (Table 2) and produced $26.7 \pm$ $0.92 \mathrm{~kg}$ of milk/d (Table 3). Advancing maturity stage generally decreased feed intake and milk yield, with the absolute lowest values observed for N90 of late maturity $(-4.1 \mathrm{~kg}$ of $\mathrm{DM} / \mathrm{d}$ and $-6.6 \mathrm{~kg}$ of milk/d, respectively, relative to preceding maturity stages). Except for the late maturity grass silage, $\mathrm{N}$ fertilization increased feed intake $(2.2 \mathrm{~kg}$ of $\mathrm{DM} / \mathrm{d})$ and milk yield $(3.4 \mathrm{~kg} / \mathrm{d})$, and a significant interaction between fertilization level and maturity occurred. A similar trend was observed for total-tract CP digestibility (on average, $0.688 \pm$ 0.0127 ; Table 2). Total-tract digestibility of OM (0.744 $\pm 0.0097), \mathrm{NDF}(0.702 \pm 0.0142)$, and $\operatorname{ADF}(0.620 \pm$ $0.0164)$ decreased with advancing maturity stage but a significant interaction between maturity and fertilization level indicated that this decline was more pronounced for N90 than for N45. Milk protein content $(30.5 \pm 0.26 \mathrm{~g} / \mathrm{kg})$ decreased for N90 but not N45 with advancing maturity stage, whereas effects were not significant for milk fat content $(42.5 \pm 1.21 \mathrm{~g} / \mathrm{kg})$. The urea content $(37.6 \pm 1.39 \mathrm{mg} / \mathrm{dL}$ of milk) was higher for N90 (Table 3).

Rumen Fermentation End-Products. The acetic acid content in rumen liquid generally increased with advancing maturity of the grass silage but effects of $\mathrm{N}$ fertilization levels on acetic acid were less clear. A similar but opposite trend was observed for valeric acid and the branched-chain VFA, whereas all other VFA, rumen $\mathrm{pH}$, and ammonia content were not affected by basal diet treatments, although significant interaction between fertilization and maturity was present for the molar proportion of butyric acid (Table 4).

Rumen Degradation. Rumen in situ degradability of the 6 grass silage treatments (Table 5) showed generally higher fractional degradation rates $\left(\boldsymbol{K}_{\mathbf{D}}\right)$ for N90 for the different feed fractions, whereas grass silage maturity had less clear effects on $K_{\mathrm{D}}$. Dietary treatments had unclear effects on the potentially degradable fraction $D$, the washable fraction $W$, and the undegradable fraction $U$. The lag time appeared to increase with 
Table 2. Feed intake and digestibility of rations containing grass silages at 2 nitrogen fertilization levels (45 and $90 \mathrm{~kg}$ of N/ha; N45 and N90, respectively) and harvested at early through late maturity

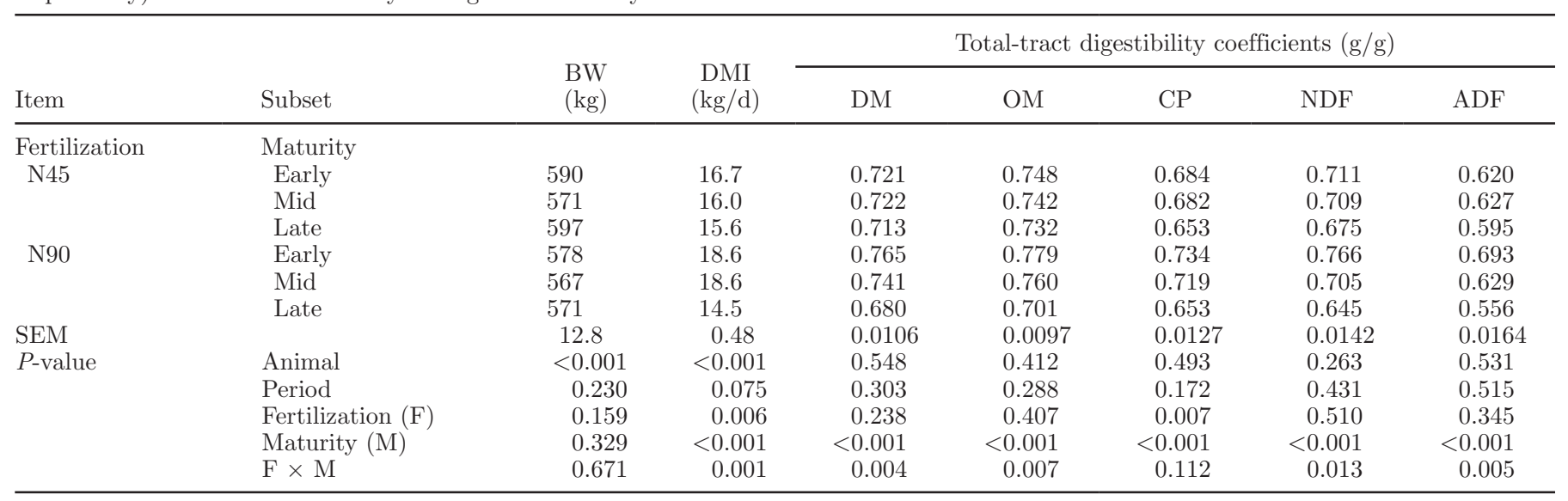

advancing maturity. With advancing maturity, fraction $D$ of NDF decreased and fraction $U$ of NDF clearly increased.

\section{Passage Kinetics}

Fecal Sampling. Passage kinetics estimated by marker techniques from fecal samples were affected by the type of marker. Fractional passage rates for the compartment with the highest retention time $\left(K_{1}\right.$; reticulorumen) were highest for Cr-NDF (0.047 $\pm 0.0030 / \mathrm{h}$; Table 6). Among stable isotope markers, $K_{1}$ differed with lower values for ${ }^{13} \mathrm{CADF}(0.023 \pm 0.0017 / \mathrm{h}) \mathrm{com}-$ pared with ${ }^{13} \mathrm{CDM}(0.034 \pm 0.0023 / \mathrm{h})$. No differences between fractions were observed for ${ }^{15} \mathrm{~N}$. Similarly, fractional passage rates for the compartment with the second highest retention time ( $K_{2}$; proximal colon-cecum) differed among markers, with higher $K_{2}$ values for ${ }^{15} \mathrm{~N}$ than ${ }^{13} \mathrm{C}$ markers (Table 6). Marker peak concentration time (PCT) was higher for the ADF (21.2 and 24.3 $\mathrm{h}$ for ${ }^{15} \mathrm{~N}$ and ${ }^{13} \mathrm{C}$ markers, respectively) than for the DM fractions (17.4 and $21.1 \mathrm{~h}$ for ${ }^{15} \mathrm{~N}$ and ${ }^{13} \mathrm{C}$ markers, respectively; Table 7). Marker PCT was lowest for ${ }^{15} \mathrm{NDM}$ among markers $(17.4 \pm 0.38 \mathrm{~h})$. Marker transit time was, on average, $10.8 \pm 0.97 \mathrm{~h}$ across markers and similarly affected by marker type $(P<0.001$; data not shown). Total mean retention time (TMRT) was lowest for Cr-NDF $(38.0 \pm 1.53 \mathrm{~h})$ and considerably longer for ${ }^{13} \mathrm{CADF}(61.1 \pm 2.80 \mathrm{~h})$ compared with ${ }^{13} \mathrm{CDM}(45.6$ $\pm 1.91 \mathrm{~h}$; Table 7). No difference was observed between the DM and ADF fractions for ${ }^{15} \mathrm{~N}(42.0$ and $46.4 \mathrm{~h}$, respectively). Fecal samples were almost fully depleted of Cr-NDF by the time sampling was terminated $120 \mathrm{~h}$ after pulse dose administration, as shown by the estimated mean marker clearance time $(114 \pm 4.6 \mathrm{~h})$ from the gastrointestinal tract. Concentration of $\delta^{15} \mathrm{~N}$ and

Table 3. Milk yield and composition for 6 dairy cows fed rations containing grass silages at 2 nitrogen fertilization levels (45 and $90 \mathrm{~kg}$ of $\mathrm{N} /$ ha; N45 and N90, respectively) and harvested at early through late maturity

\begin{tabular}{|c|c|c|c|c|c|c|c|c|}
\hline Item & Subset & \multicolumn{3}{|c|}{ Milk yield (kg/d) } & \multicolumn{4}{|c|}{ Composition $(\mathrm{g} / \mathrm{kg} \text { of milk })^{1}$} \\
\hline Fertilization & Maturity & & & & & & & \\
\hline \multirow{2}{*}{ N45 } & Mid & 24.9 & 1.08 & 0.76 & 43.2 & 30.8 & 45.7 & 35.9 \\
\hline & Late & 24.5 & 1.06 & 0.74 & 43.0 & 30.4 & 45.3 & 37.0 \\
\hline N90 & Early & 29.8 & 1.32 & 0.96 & 44.0 & 32.0 & 45.8 & 38.1 \\
\hline \multirow[t]{5}{*}{$P$-value } & Animal & $<0.001$ & $<0.001$ & $<0.001$ & $<0.001$ & $<0.001$ & 0.017 & 0.004 \\
\hline & Period & 0.001 & $<0.001$ & 0.012 & $<0.001$ & $<0.001$ & 0.005 & $<0.001$ \\
\hline & Fertilization $(\mathrm{F})$ & 0.015 & 0.035 & 0.006 & 0.776 & 0.648 & 0.418 & 0.008 \\
\hline & Maturity (M) & $<0.001$ & 0.001 & $<0.001$ & 0.339 & $<0.001$ & 0.085 & 0.080 \\
\hline & $\mathrm{F} \times \mathrm{M}$ & 0.005 & 0.007 & 0.001 & 0.056 & $<0.001$ & 0.387 & 0.524 \\
\hline
\end{tabular}

${ }^{1}$ Milk composition analyzed by mid-infrared reflection spectroscopy (Milk Control Station VVB, Nunspeet, the Netherlands); milk urea expressed as $\mathrm{mg} / 100 \mathrm{~mL}$ of milk. 
Table 4. Rumen liquid characteristics of dairy cows fed 2 grass silages (45 and $90 \mathrm{~kg}$ of N/ha; N45 and N90, respectively) harvested at early through late maturity

\begin{tabular}{|c|c|c|c|c|c|c|c|c|c|c|}
\hline \multirow[b]{2}{*}{ Item } & \multirow[b]{2}{*}{ Subset } & \multirow[b]{2}{*}{$\mathrm{pH}$} & \multicolumn{8}{|c|}{ Rumen liquid composition ${ }^{1}$} \\
\hline & & & $\mathrm{HAc}$ & HPr & $\mathrm{HBu}$ & $\mathrm{HVa}$ & $\mathrm{HBc}$ & tVFA & NGR & $\mathrm{NH}_{3}$ \\
\hline \multirow{3}{*}{ N45 } & Early & 6.30 & 65.0 & 19.0 & 11.8 & 1.49 & 2.68 & 106.0 & 4.29 & 3.4 \\
\hline & Mid & 6.08 & 67.5 & 18.2 & 11.0 & 1.19 & 2.17 & 108.4 & 4.58 & 3.9 \\
\hline & Late & 6.08 & 67.3 & 17.9 & 11.6 & 1.14 & 1.97 & 106.9 & 4.65 & 4.2 \\
\hline N90 & Early & 6.14 & 65.4 & 18.7 & 11.8 & 1.36 & 2.73 & 115.4 & 4.38 & 5.3 \\
\hline SEM & & 0.044 & 0.58 & 0.55 & 0.358 & 0.064 & 0.127 & 3.07 & 0.154 & 0.53 \\
\hline \multirow[t]{6}{*}{$P$-value ${ }^{2}$} & Animal & 0.010 & 0.066 & 0.026 & 0.566 & 0.107 & 0.018 & $<0.001$ & 0.030 & 0.591 \\
\hline & Period & $<0.001$ & 0.016 & 0.233 & 0.061 & 0.233 & 0.037 & 0.008 & 0.224 & 0.530 \\
\hline & Fertilization $(\mathrm{F})$ & 0.350 & 0.037 & 0.949 & 0.117 & 0.019 & $<0.001$ & 0.339 & 0.714 & 0.191 \\
\hline & Maturity (M) & 0.119 & 0.002 & 0.156 & 0.203 & 0.008 & 0.003 & 0.184 & 0.151 & 0.417 \\
\hline & $\mathrm{F} \times \mathrm{M}$ & 0.003 & 0.004 & 0.792 & 0.004 & 0.002 & 0.020 & 0.097 & 0.692 & 0.070 \\
\hline & Time $(\mathrm{T})$ & $<0.001$ & $<0.001$ & $<0.001$ & 0.972 & $<0.001$ & $<0.001$ & $<0.001$ & $<0.001$ & $<0.001$ \\
\hline
\end{tabular}

${ }^{1} \mathrm{HAc}=$ acetic acid; $\mathrm{HPr}=$ propionic acid; $\mathrm{HBu}=$ butyric acid; $\mathrm{HVa}=$ valeric acid; $\mathrm{HBc}=$ branched-chain VFA (isobutyric + isovaleric acid); tVFA $=$ total VFA (in mmol/L; HAc $+\mathrm{HPr}+\mathrm{HBu}+\mathrm{HVa}+\mathrm{HBc}) ; \mathrm{NGR}=$ nonglucogenic to glucogenic VFA ratio $[=(\mathrm{HAc}+2 \times \mathrm{HBu}+2$ $\times$ isobutyric $+\mathrm{HVa}+$ isovaleric $) /(\mathrm{HPr}+\mathrm{HVa}+$ isovaleric $)] ; \mathrm{NH}_{3}=$ ammonia $(\mathrm{mmol} / \mathrm{L})$. All values expressed in mol/100 mol unless specified otherwise.

${ }^{2}$ Analyses of variance based on log-transformed means with subplot $\mathrm{T}$ (time; 2, 6, 8, and $10 \mathrm{~h}$ after morning feeding) within factorial main plots in a Latin square.

$\delta^{13} \mathrm{C}$ at $120 \mathrm{~h}$ was still above the natural abundance level, as indicated by the total marker clearance time of 126 to $137 \mathrm{~h}$ for the DM fraction and 139 to $183 \mathrm{~h}$ for the ADF fraction. Medians for model parameters $A$ (a scalable parameter) and $N$ (model-derived number of compartments), as estimated by the multicompartmental model, were $2.3(P<0.001)$ and $24(P>0.10)$ across markers, respectively (data not shown). The

Table 5. Rumen degradation kinetics of rations containing grass silages at 2 nitrogen fertilization levels (45 and $90 \mathrm{~kg}$ of N/ha; N45 and N90, respectively) and harvested at early through late maturity fed to 6 lactating dairy cows

\begin{tabular}{|c|c|c|c|c|c|c|c|}
\hline \multirow{2}{*}{$\begin{array}{l}\text { Degradation } \\
\text { parameter }^{1}\end{array}$} & \multicolumn{3}{|c|}{ N45 } & \multicolumn{3}{|c|}{ N90 } & \multirow[b]{2}{*}{ SEM } \\
\hline & Early & Mid & Late & Early & Mid & Late & \\
\hline \multicolumn{8}{|l|}{$\mathrm{OM}$} \\
\hline$K_{\mathrm{D}}$ & 0.035 & 0.032 & 0.032 & 0.048 & 0.049 & 0.052 & 0.0055 \\
\hline$D$ & 59.0 & 69.9 & 63.1 & 57.9 & 56.6 & 51.3 & 3.64 \\
\hline$W$ & 15.3 & 19.1 & 24.5 & 14.8 & 17.7 & 34.3 & 3.28 \\
\hline$U$ & 25.8 & 11.0 & 12.4 & 27.3 & 25.7 & 14.4 & 1.47 \\
\hline Lag & 0.4 & 0.0 & 2.1 & 2.4 & 5.4 & 6.6 & 1.94 \\
\hline \multicolumn{8}{|l|}{$\mathrm{CP}$} \\
\hline$K_{\mathrm{D}}$ & 0.060 & 0.042 & 0.052 & 0.072 & 0.059 & 0.063 & 0.0069 \\
\hline$D$ & 34.5 & 54.0 & 50.6 & 45.4 & 33.3 & 32.4 & 1.88 \\
\hline$W$ & 17.0 & 19.3 & 30.4 & 12.7 & 14.6 & 30.5 & 0.95 \\
\hline$U$ & 48.5 & 26.7 & 19.0 & 41.9 & 52.2 & 37.0 & 1.53 \\
\hline Lag & 0.0 & 0.0 & 0.0 & 2.7 & 0.0 & 2.5 & 1.36 \\
\hline \multicolumn{8}{|l|}{$\mathrm{NDF}$} \\
\hline$K_{\mathrm{D}}$ & 0.028 & 0.034 & 0.024 & 0.040 & 0.048 & 0.050 & 0.0070 \\
\hline$D$ & 87.5 & 77.1 & 79.7 & 81.9 & 75.5 & 59.5 & 5.24 \\
\hline$U$ & 12.5 & 22.9 & 20.3 & 18.2 & 24.5 & 40.5 & 5.24 \\
\hline Lag & 2.6 & 3.2 & 4.4 & 6.1 & 9.2 & 9.4 & 1.97 \\
\hline \multicolumn{8}{|l|}{$\mathrm{ADF}$} \\
\hline$K_{\mathrm{D}}$ & 0.030 & 0.036 & 0.022 & 0.030 & 0.042 & 0.041 & 0.0050 \\
\hline$D$ & 80.0 & 75.5 & 79.4 & 85.2 & 77.8 & 60.3 & 5.19 \\
\hline$U$ & 20.0 & 24.5 & 20.6 & 14.8 & 22.2 & 39.7 & 5.19 \\
\hline Lag & 1.6 & 5.7 & 4.7 & 5.3 & 8.2 & 7.6 & 2.26 \\
\hline
\end{tabular}

${ }^{1}$ Degradation parameters: $K_{\mathrm{D}}=$ fractional degradation rate constant $(/ \mathrm{h})$ of $D$ fraction; $D=$ potentially degradable and insoluble fraction $(\% ; D=100-W-U) ; W=$ washable fraction (\%; assumed zero for the NDF and $\mathrm{ADF}$ fraction); $U=$ undegradable fraction at $t=\infty(\%) ; \operatorname{lag}=$ lag time. 
MPE as an indicator of curve fit accuracy was lowest for Cr-NDF $(9.7 \pm 0.72 \% ; P<0.001)$ among markers. Interestingly, MPE was lower with ${ }^{15} \mathrm{~N}(11.0-13.7 \%)$ than with ${ }^{13} \mathrm{C}$ markers $(22.1-24.0 \% ; P<0.001)$. The largest proportion of the MPE across markers was due to random variation (96.5\%) and only a minor part was explained by mean bias (1.5\%) or regression bias (1.9\%; data not shown). Basal diet treatment generally affected passage kinetics. Treatment effects on $K_{1}$ were less clear; $K_{1}$ tended to be higher for N90 (0.035 \pm $0.0019 / \mathrm{h})$ compared with N45 $(0.031 \pm 0.0020 / \mathrm{h})$ but did not change with maturity. Similarly, $K_{1}$ increased from 0.32 to $0.24 / \mathrm{h}$ and TMRT decreased from 49.1 to 43.1 h with N90 compared with N45. Maturity stage had unclear effects on passage kinetics.

Omasal Sampling. Passage kinetics ( $K_{1}$, TMRT) based on omasal grab sampling showed a trend similar to that based on fecal grab sampling (Table 8). Passage kinetics were not affected by maturity stage but $K_{1}$ was higher for N90 $(0.037 \pm 0.0017 / \mathrm{h})$ than for N45 $(0.030$ $\pm 0.0016 / \mathrm{h})$. Nitrogen fertilization decreased TMRT from $34.7 \mathrm{~h}$ (N45) to $28.3 \mathrm{~h}$ (N90). The marker effect was significant for $K_{1}$ and TRMT. Estimates of $K_{2}$ averaged $1.96 \pm 2.441 / \mathrm{h}(P>0.10$ for marker effect $)$. Medians for model parameters $A$ and $N$ were $1.1(P<$ $0.001)$ and $4.0(P>0.10)$ across markers, respectively (data not shown). The MPE for Cr-NDF curve fit was $24.7 \pm 1.56 \%$ and in range with that for ${ }^{13} \mathrm{C}$ and ${ }^{15} \mathrm{~N}$ curve fits (16.6-27.8\%; data not shown). Mean $\mathrm{pH}$ of omasal digesta was $6.51 \pm 0.012$.

\section{DISCUSSION}

\section{Feed Characteristics}

Because availability of established ryegrass swards was restricted, the early maturity N45 and N90 treatments were prepared from the third regrowth following the respective mid maturity treatment. With this harvest schedule, a possible mid-summer growing period for the early maturity treatments could be avoided, and with it the risk of obtaining potentially stemmy plant material (Khan et al., 2011) for our early-cut grass typically low in structural fiber and high in $\mathrm{CP}$ content. However, a potential accumulation of $\mathrm{N}$ with the third regrowth material (early maturity) relative to the second regrowth material (mid and late maturity) need to be taken into account. Nonetheless, nutritional contrasts among treatments were substantial and allowed us to test the sensitivity of the different passage markers to changes in the diet composition. The treatments imposed had a clear effect on CP content. In contrast, NDF content was little affected by $\mathrm{N}$ fertilization but more by maturity stage and is essentially in agreement with previous findings (Valk et al., 1996; Peyraud and Astigarraga, 1998). The observed clus-

Table 6. Fractional passage rates of different markers as determined by fecal sampling for lactating dairy cows fed rations containing grass silages at 2 nitrogen fertilization levels (45 and $90 \mathrm{~kg}$ of N/ha; N45 and N90, respectively) and harvested at early through late maturity ${ }^{\mathrm{P}}$

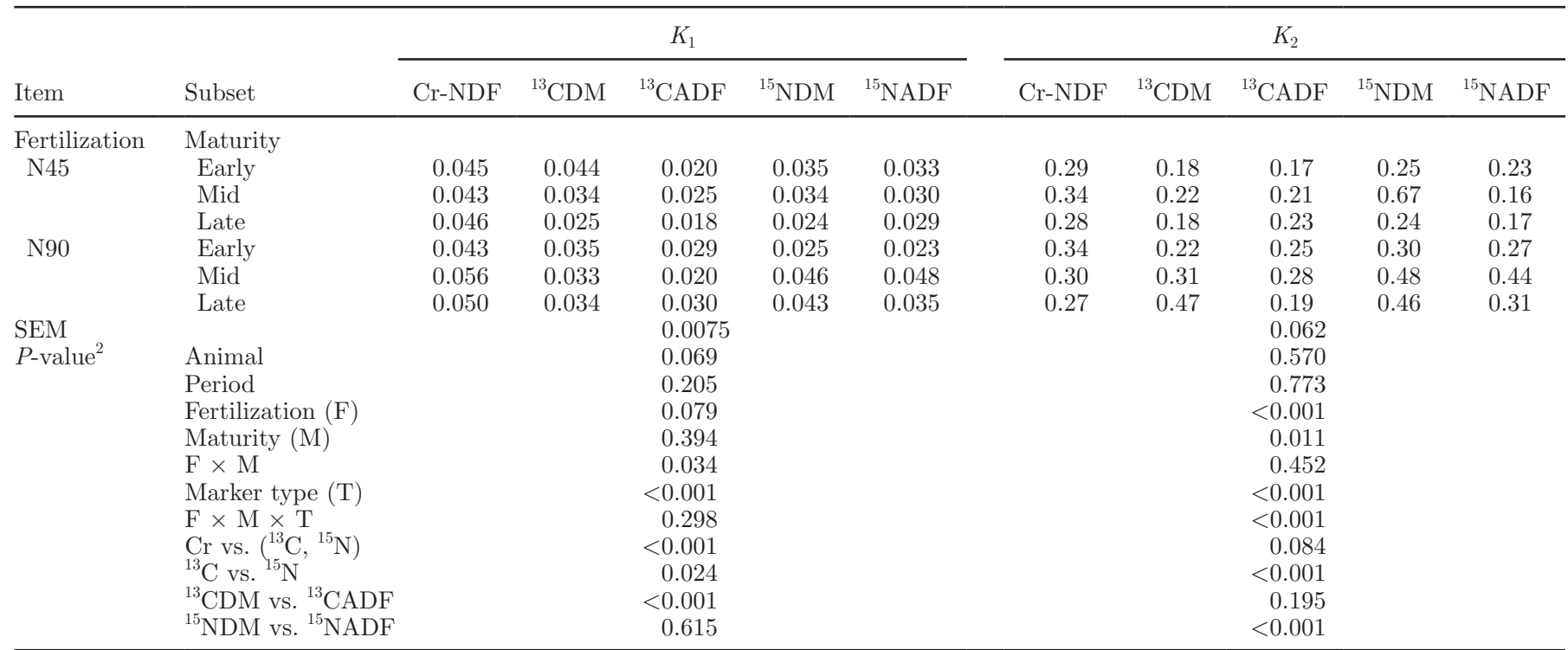

${ }^{1}$ Fractional passage parameters: $K_{1}=$ fractional passage rate constant $(/ \mathrm{h})$ for the compartment with the highest retention time in the gastrointestinal tract (i.e., the reticulorumen); $K_{2}=$ fractional passage rate constant $(/ \mathrm{h}$ ) for the compartment with the second highest retention time in the gastrointestinal tract (i.e., the proximal colon-cecum). Markers: chromium mordanted fiber $(\mathrm{Cr}-\mathrm{NDF}) ;{ }^{13} \mathrm{C}$ in the DM $\left({ }^{13} \mathrm{CDM}\right)$ and the $\mathrm{ADF}\left({ }^{13} \mathrm{CADF}\right) ;{ }^{15} \mathrm{~N}$ in the DM $\left({ }^{15} \mathrm{NDM}\right)$ and the ADF $\left({ }^{15} \mathrm{NADF}\right)$.

${ }^{2}$ Analyses of variance with orthogonal contrasts between markers based on log-transformed means in a split-plot arrangement with factorial main plots in a Latin square. 
Table 7. Marker residence time in the gastrointestinal tract as determined by fecal sampling for lactating dairy cows fed rations containing grass silages at 2 nitrogen fertilization levels (45 and $90 \mathrm{~kg}$ of N/ha; N45 and N90, respectively) and harvested at early through late maturity ${ }^{\mathrm{D}}$

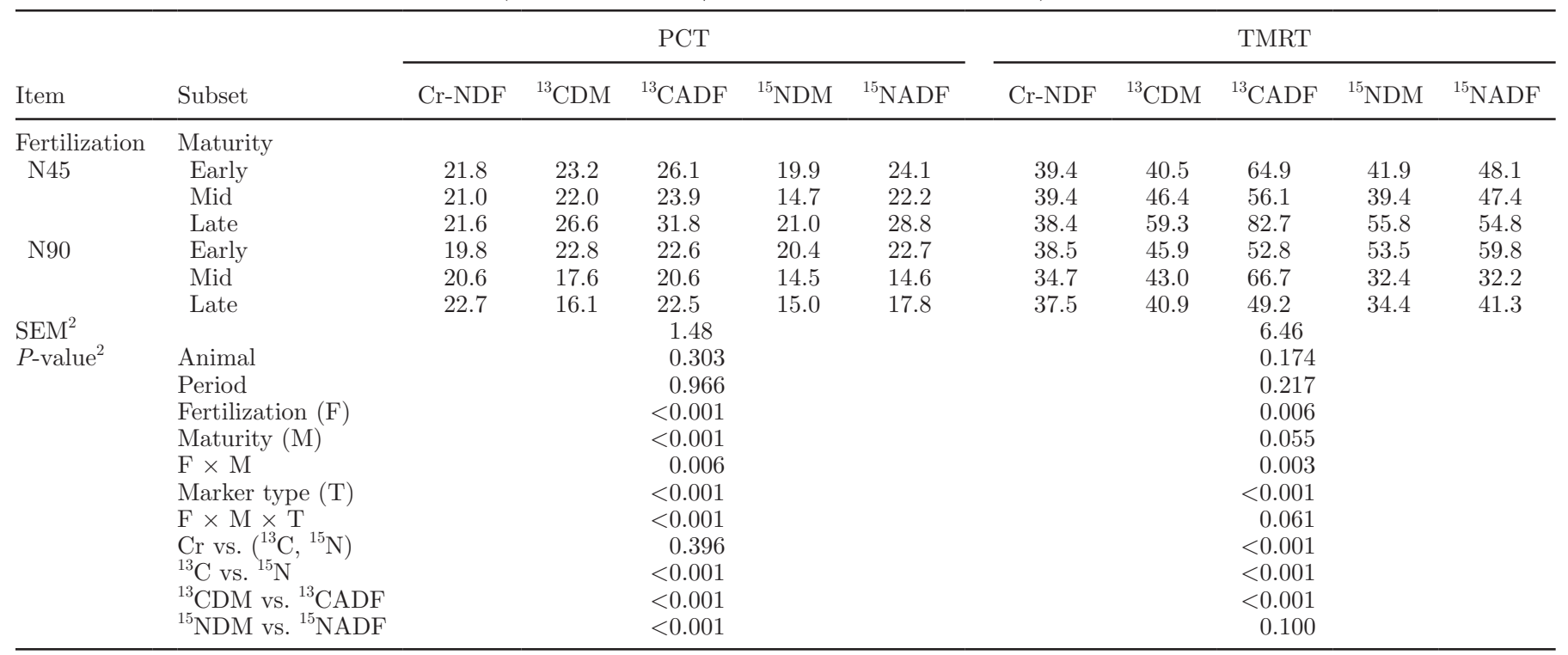

${ }^{1}$ Residence time parameters: PCT $=$ marker peak concentration time in feces $(\mathrm{h})$; TMRT $=$ total mean retention time in the gastrointestinal tract (h). Markers: chromium mordanted fiber (Cr-NDF); ${ }^{13} \mathrm{C}$ in the DM $\left({ }^{13} \mathrm{CDM}\right)$ and the ADF $\left({ }^{13} \mathrm{CADF}\right) ;{ }^{15} \mathrm{~N}$ in the DM $\left({ }^{15} \mathrm{NDM}\right)$ and the $\mathrm{ADF}\left({ }^{15} \mathrm{NADF}\right)$.

${ }^{2}$ Analyses of variance with orthogonal contrasts between markers based on log-transformed means in a split-plot arrangement with factorial main plots in a Latin square.

Table 8. Rumen passage kinetics of different markers as determined by omasal sampling for lactating dairy cows fed rations containing grass silages at 2 nitrogen fertilization levels (45 and $90 \mathrm{~kg}$ of N/ha; N45 and N90, respectively) and harvested at early through late maturity

\begin{tabular}{|c|c|c|c|}
\hline \multirow[b]{2}{*}{ Item } & \multicolumn{3}{|c|}{ Passage kinetic parameter ${ }^{1}$} \\
\hline & $K_{1}$ & $K_{2}$ & TMRT \\
\hline \multicolumn{4}{|l|}{ Marker $^{2}$} \\
\hline Cr-NDF & 0.042 & 1.35 & 25.7 \\
\hline${ }^{13} \mathrm{CDM}$ & 0.034 & 2.18 & 29.7 \\
\hline${ }^{13} \mathrm{CADF}$ & 0.024 & 1.38 & 42.8 \\
\hline${ }^{15} \mathrm{NDM}$ & 0.036 & 2.01 & 29.3 \\
\hline${ }^{15} \mathrm{NADF}$ & 0.034 & 1.12 & 31.6 \\
\hline SEM & 0.0059 & 2.441 & 9.84 \\
\hline \multicolumn{4}{|l|}{$P$-value ${ }^{3}$} \\
\hline Animal & 0.034 & 0.746 & 0.007 \\
\hline Period & 0.239 & 0.437 & 0.335 \\
\hline Fertilization (F) & 0.012 & 0.162 & 0.009 \\
\hline Maturity (M) & 0.257 & 0.506 & 0.272 \\
\hline $\mathrm{F} \times \mathrm{M}$ & 0.057 & 0.739 & 0.060 \\
\hline Marker type (T) & $<0.001$ & 0.386 & $<0.001$ \\
\hline $\mathrm{F} \times \mathrm{M} \times \mathrm{T}$ & 0.028 & 0.153 & $<0.001$ \\
\hline Cr vs. $\left({ }^{13} \mathrm{C},{ }^{15} \mathrm{~N}\right)$ & $<0.001$ & 0.466 & $<0.001$ \\
\hline${ }^{13} \mathrm{C}$ vs. ${ }^{15} \mathrm{~N}$ & $<0.001$ & 0.593 & 0.016 \\
\hline${ }^{13} \mathrm{CDM}$ vs. ${ }^{13} \mathrm{CADF}$ & $<0.001$ & 0.222 & $<0.001$ \\
\hline${ }^{15} \mathrm{NDM}$ vs. ${ }^{15} \mathrm{NADF}$ & 0.534 & 0.133 & 0.419 \\
\hline
\end{tabular}

${ }^{1}$ Parameter: $K_{1}=$ fractional passage rate constant $(/ \mathrm{h})$ for the compartment with the highest retention time in the reticulorumen; $K_{2}=$ fractional passage rate constant $(/ \mathrm{h})$ for the compartment with the second highest retention time in the reticulorumen; TMRT $=$ total mean retention time in the reticulorumen $(\mathrm{h})$.

${ }^{2}$ Marker: $\mathrm{Cr}-\mathrm{NDF}=$ chromium mordanted fiber; ${ }^{13} \mathrm{CDM}={ }^{13} \mathrm{C}$ in the $\mathrm{DM} ;{ }^{13} \mathrm{CADF}={ }^{13} \mathrm{C}$ in the ADF; ${ }^{15} \mathrm{NDM}$ $={ }^{15} \mathrm{~N}$ in the DM; ${ }^{15} \mathrm{NADF}={ }^{15} \mathrm{~N}$ in the ADF.

${ }^{3}$ Analyses of variance with orthogonal contrasts between markers based on log-transformed means in a splitplot arrangement with factorial main plots in a Latin square. 
ters of grass silage NDF between maturity stages (i.e., comparable NDF levels for N45 between mid and late maturity in contrast to comparable NDF levels for N90 between early and mid maturity) might be explained by the later growing cycle of the early maturity grass silage and the varying dates on and conditions under which grass was harvested.

\section{Animal Characteristics}

The nutritional composition of the grass silage fed had a substantial effect on feed intake. The observed higher feed intake with higher $\mathrm{N}$ fertilization is in line with observations on fresh grass (Mackle et al., 1996). Negative effects of advancing grass silage maturity on feed intake levels were also observed by Bosch et al. (1992b) and Tahir et al. (2013). The distinctive decrease in feed intake of late-cut N90 relative to preceding maturity stages matched with a low OM digestibility and highest absolute NDF and ADF contents for that particular treatment combination. Moreover, apparent total diet $\mathrm{CP}$ and $\mathrm{OM}$ digestibility was low. However, no deficiency in ruminal degradable protein (as indicated by the positive OEB value) for optimal microbial fermentation was observed, which could impair ruminal digestion and consequently feed intake (Romney and Gill, 2000). The distinctive changes in milk and milk component yields with late-cut N90 are in line with the overall reduced $\mathrm{NE}_{\mathrm{L}}$ and feed intake observed with that particular treatment combination. Grass silage maturity increased the molar proportion of acetic acid in the rumen but did not change that of propionic acid or the nonglucogenic to glucogenic VFA ratio, which agrees with literature findings as reviewed by Rinne et al. (1997b).

\section{Passage Kinetics of Grass Silage}

Effect of Maturity Stage and Fertilization Level on Passage Kinetics. Effects of $\mathrm{N}$ fertilization on passage kinetics of grass silages have not been investigated by researchers. In contrast, effects of advancing grass silage maturity on passage kinetics have been rather extensively studied but are ambiguous and seem to depend on the plant material and resulting specific particle size. Although some studies reported reduced or unchanged $K_{1}$ values for late compared with early maturing grass (Mambrini and Peyraud, 1994; Lamb et al., 2002; Lund et al., 2006; Kuoppala et al., 2009; Bayat et al., 2010, 2011), other studies showed increased $K_{1}$ values with advancing maturity of grass silage (Gasa et al., 1991; Bosch et al., 1992a; Rinne et al., 1997a, 2002). In our study, $K_{1}$ was generally higher and passage kinetics faster (higher $K_{2}$; lower $\mathrm{PCT}$, transit time, and TMRT) for the high fertilized N90 treatment. In contrast, grass silage maturity did not have a clear effect on passage kinetics, and we observed a strong interaction between plant maturity and $\mathrm{N}$ fertilization on $K_{1}$. Differences in the DM content of our grass silages might have partly masked treatment effects, most likely via an altered fermentation profile and reduced overall fermentation of grass silage with increasing DM content, as observed by van Vuuren et al. (1989). The interaction between plant maturity and $\mathrm{N}$ fertilization observed in our study could explain the inconclusive findings observed in an earlier study (Pellikaan et al., 2013). In that study, high digestible grass silage (100 kg of N/ha; 39-d regrowth) did not result in a measurable change in passage kinetics compared with a low digestible grass silage (50 kg of $\mathrm{N} / \mathrm{ha}$; 81-d regrowth), as could have been expected based on the large nutritional contrasts of the grass silages. Furthermore, Owens et al. (2008a,b) reported increased $K_{1}$ values of fresh ryegrass harvested at a later stage for the high CP (165-192 g/ $\mathrm{kg}$ of DM) autumn regrowth but not so for the low CP (99-116 g/kg of DM) spring regrowth.

Potential Effects of Particle Size on Passage Kinetics. Digesta particle size was not measured in this study but effects of particle size on $K_{1}$ have been reported in the literature. For grass silage in particular, advancing plant maturity was observed to increase $K_{1}$ in line with a reduced digesta particle size and increased particle breakdown rate for the small particle pool in the rumen for a late-cut compared with an early-cut grass silage (Rinne et al., 2002; Krämer et al., 2013). Similarly, advancing maturity stage of grass silage considerably decreased the proportion of large particles $(>1.0 \mathrm{~mm})$ and increased that of small particles $(0.2-0.5 \mathrm{~mm})$ in feces (Jalali et al., 2012). Furthermore, Rinne et al. (2002) observed a higher fragility or brittleness of the more lignified particles from latecut grass silage. We can therefore hypothesize that the increased brittleness of leaves often observed with the more mature plant material (Ulyatt, 1983) in combination with an increased leaf blade size upon increased $\mathrm{N}$ fertilization (Wilman and Pearse, 1984) resulted in a considerable particle size reduction of ${ }^{15} \mathrm{NDM}$ and ${ }^{15} \mathrm{NADF}$ from leaves and, consequently, in increased passage kinetics for the late-cut N90. These changes in passage kinetics of $\delta^{15} \mathrm{~N}$ with advancing plant maturity were not observed for the $\delta^{13} \mathrm{C}$ fractions. This is likely due to overall lower particle size reduction of stems than leaves of grass (Poppi et al., 1981; Cherney et al., 1991). Furthermore, changes in the cell wall structure are probably of minor importance to $K_{1}$ because cell wall composition (Wilman et al., 1977) and stem morphology (Harris et al., 1996) seem to be unaffected by the level of $\mathrm{N}$ fertilization. 
Relationship Between Fractional Rates of Degradation and Passage. Degradation kinetics were investigated to test a potential relationship with passage kinetics. It is generally assumed that a quicker rumen degradation increases buoyancy of feed particles through entrapment of fermentation gases, and that buoyant particles are in turn less likely to escape from the reticulorumen (Sutherland, 1988). Higher fertilization appeared to increase $K_{\mathrm{D}}$ of the grass silages tested, essentially in agreement with previous literature (van Vuuren et al., 1991; Valk et al., 1996; Peyraud et al., 1997) and in line with the trends observed for $K_{1}$ in our study. Effects of advancing grass silage maturity on degradation kinetics were, however, inconclusive. In general, $K_{\mathrm{D}}$ was not well correlated with $K_{1}$ based on our data set $(\mathrm{r} \leq 0.40 ; \mathrm{n}=34)$. The highest correlation coefficients were obtained among fiber $K_{\mathrm{D}}$ and $K_{1}$ based on ${ }^{13} \mathrm{CADF}$ and ${ }^{15} \mathrm{NADF}(\mathrm{r}=0.25$ to 0.40$)$ but with regard to other nutrients, stable isotopes did not particularly result in higher r-values than Cr-NDF. In a previous experiment with corn silage and using ${ }^{13} \mathrm{CDM}$ and ${ }^{13} \mathrm{CADF}$ as internal markers, no direct link could be established between silage degradation and passage rates (Warner et al., 2013a).

\section{Choice of Marker and Sampling Site to Estimate Passage Kinetics}

Passage kinetics of $\delta^{13} \mathrm{C}$ and $\delta^{15} \mathrm{~N}$ in apparent undigested feed components in feces were compared with those of Cr-NDF, an external particulate marker frequently reported in the literature. The use of indigestible feed nutrients as inert internal passage markers (e.g., indigestible NDF) were not investigated because estimating $K_{1}$ on intact animals requires a different approach than the marker technique outlined here (i.e., frequent rumen emptying is required to determine the pool size). Furthermore, the feed component tested is required to be strictly indigestible. In contrast, isotopelabeled feed components can be digested. However, digestion does not affect the isotopic ratio (Pellikaan et al., 2013) based on which fractional passage rate can be estimated from fecal isotope excretion patterns. In our study, passage kinetics were derived from both fecal and omasal digesta samples, and passage kinetics of the grass silage were highly dependent on the type of marker $(P<0.001)$.

Carbon Stable Isotopes as Internal Passage Markers. The external marker $\mathrm{Cr}-\mathrm{NDF}$ provided $K_{1}$ values approximately $0.016 / \mathrm{h}$ units higher and, in turn, a TMRT 10.8-h lower than the internal ${ }^{13} \mathrm{C}$ and ${ }^{15} \mathrm{~N}$ markers. Similar findings were reported for $\mathrm{Cr}-\mathrm{NDF}$ and $\delta^{13} \mathrm{C}$ from labeled grass silage (Pellikaan et al., 2013) and corn silage (Warner et al., 2013a). The ADF fraction had considerably slower passage kinetics than the DM fraction when $\delta^{13} \mathrm{C}$ was used $\left(K_{1}\right.$ reduced by $0.011 / \mathrm{h}$; TMRT increased by $15.5 \mathrm{~h}$; PCT increased by $3.3 \mathrm{~h}$ ). In contrast, differences in $K_{1}$ between the 2 fractions were almost absent with corn silage $\left(K_{1}\right.$ of $0.023 / \mathrm{h}$ and $0.021 / \mathrm{h}$ for ${ }^{13} \mathrm{CDM}$ and ${ }^{13} \mathrm{CADF}$ respectively; Warner et al., 2013a). With grass silage, differences were higher in the study of Pellikaan et al. (2013) to some extent, although differences were dependent on the silage quality (difference of -0.019 and $-0.023 / \mathrm{h}$ for high and low digestible grass silage, respectively). We found a similar silage quality effect on the relation between ${ }^{13} \mathrm{CDM}$ and ${ }^{13} \mathrm{CADF}$ with differences in $K_{1}$ being amplified for the low fertilized grass (difference of -0.008 and $-0.014 / \mathrm{h}$ for N90 and N45, respectively). These results may reflect the different physical structure of fiber between the 2 forage types (De Boever et al., 1993a,b) and between forage quality.

Nitrogen Stable Isotopes as Internal Passage Markers. When $\delta^{15} \mathrm{~N}$ was used, the ADF fraction had similar passage kinetics to the DM fraction, except for a somewhat reduced $K_{2}$ (by $0.125 / \mathrm{h}$ ) and a considerably increased PCT $(3.9 \mathrm{~h})$. The use of $\delta^{15} \mathrm{~N}$ provided a more detailed insight into the passage kinetics of the cell walls. The ${ }^{15} \mathrm{NADF}$ (essentially representing cell wallbound $\mathrm{N}$ ) appear to pass out at a somewhat higher rate from the reticulorumen $\left(K_{1}\right.$ increased by $\left.0.009 / \mathrm{h}\right)$ and from the gastrointestinal tract (TMRT reduced by 14.1 h) than the total cell walls $\left({ }^{13} \mathrm{CADF}\right)$. Similarly, total proteins based on ${ }^{15} \mathrm{NDM}$ appeared to have somewhat increased passage kinetics relative to the nonprotein fraction based on ${ }^{13} \mathrm{CDM}$. Overall, the experimentally determined $K_{1}$ of ${ }^{15} \mathrm{NDM}(0.034 \pm 0.0021 / \mathrm{h})$ was lower than what is assumed by the Dutch feed evaluation system (fixed to 0.045/h; van Duinkerken et al., 2011), which is based on passage studies using external markers. Based on the same feed intake levels, $K_{1}$ of ${ }^{15} \mathrm{NDM}$ from our study was lower than when calculated based on the equations used in the UK Feed-into-Milk system (0.043/h; Thomas, 2004) but in line with results based on the equations used in the National Research Council system $(0.031 / \mathrm{h} ; \mathrm{NRC}, 2001)$ and the Nordic feed evaluation system $\left(0.035 / \mathrm{h}\right.$; Volden, 2011). The $K_{1}$ of Cr-NDF in the present study $(0.047 \pm 0.0030 / \mathrm{h})$ was well in line with the assumption in the Dutch and UK system (0.045 and 0.043, respectively).

Fecal Versus Omasal Sampling. Sampling digesta more proximate to the dosing site might give more accurate fractional passage rate estimations than fecal sampling because any effects related to the small and large intestine are circumvented. In our study, sampling site had little effect on passage kinetics, suggesting that fecal sampling provide reliable ruminal passage kinetics. In addition, the same marker contrasts as well as 
the maturity $\times \mathrm{N}$ fertilization interaction observed in fecal samples were detected in omasal digesta (data not shown). Fecal marker $K_{1}$ and TMRT were moderately correlated with those based on omasal digesta sampling (on average, $\mathrm{r}=0.47$ and $\mathrm{r}=0.56$, respectively) with little difference between $\mathrm{Cr}-\mathrm{NDF}$ and stable isotope markers, except ${ }^{13} \mathrm{CADF}$ for which no correlation was observed.

Accuracy of ${ }^{13} \mathrm{C} /{ }^{15} \mathrm{~N}$-Labeled Feed Components as Passage Markers. Curve fit accuracy based on the MPE was in the range of previous studies using $\delta^{13} \mathrm{C}$ labeled forage (Pellikaan et al., 2013; Warner et al., 2013a) but MPE values were almost double compared with those reported for $\delta^{13} \mathrm{C}$-labeled concentrates pulse dosed at high amounts (9 kg; Warner et al., 2013b). Interestingly, curve fit accuracy for Cr-NDF based on fecal sampling was considerably better than that for stable isotopes, but accuracy considerably declined for Cr-NDF with omasal digesta sampling and was even slightly worse than that of $\delta^{15} \mathrm{~N}$. These findings suggest that the small ruminal pulse dose size of stable isotopes probably affected its curve fit accuracy, and that omasal sampling provided somewhat less reliable results than fecal sampling. Interestingly, curve fit accuracy of stable isotopes was not particularly worse based on omasal digesta compared with fecal sampling, as might have been expected based on the results for Cr-NDF. This suggests that satisfactory marker distribution in the rumen was probably attained well before the first omasal samples were taken. It should be noted, furthermore, that a smaller number of omasal than fecal samples were collected and submitted to analyses. Visual inspection of curve fits confirmed that the presence of a few possible outlying values weakened the fit of omasal excretion curves to a greater extent than that of fecal excretion curves, which relied on a higher number of available data points. The increased costs associated with collecting and submitting a greater number of samples to isotope analyses might be avoided by using a larger but less-enriched pulse dose size. Most likely, marker distribution within the rumen content will be accelerated, as is probably the case for the finely ground Cr-NDF particles, and lower the effect of possible outlying values on curve fit accuracy and consequently passage kinetics.

Shortcomings and advantages of using isotope-labeled feed components as digesta passage markers have been described elsewhere (Warner et al., 2013a). Although external particulate markers most likely represent feed particles of defined characteristics (as shown for CrNDF; Bosch and Bruining, 1995), stable isotopes can provide component-specific passage kinetics because isotopes are inherent to the feed and its chemical fractions. In contrast to the general requirement of strict nondigestibility for external markers and inert internal markers (e.g., indigestible NDF in combination with rumen evacuations), stable isotopes allows researchers to determine passage of indigestible and digestible feed components. However, the latter might result in a bias in $K_{1}$ due to marker migration, a problem often observed with rare earth elements (Owens and Hanson, 1992) if stable isotopes are incorporated into microbial biomass (Firkins et al., 1998; Pellikaan et al., 2013). The acid detergent treatment circumvents this problem because none or only negligible amounts of digestible fractions are analytically recovered in this fraction. However, digestible fractions are more prone to bias, and it has been shown that up to $8 \mathrm{~g}$ of $\mathrm{C} / \mathrm{kg}$ of fecal DM was of microbial origin (van Vliet et al., 2007) and that the fecal microbial biomass increased with decreasing grass silage maturity. Hence, marker migration via microbial biomass might, in theory, introduce some bias with DM or intracellular matter but overall effects on the $K_{1}$ of digestible fractions will be probably minor.

Based on our results, further applications of stable isotopes on a wider range of feeds and feed components in combination with alternative marker techniques are necessary to confirm the validity of isotope-labeled feed components as digesta passage markers.

\section{CONCLUSIONS}

The use of $\delta^{13} \mathrm{C}$ and $\delta^{15} \mathrm{~N}$ stable isotopes from intrinsically labeled ryegrass silage allowed the assessment of passage kinetics of fiber and fiber-bound N. Fractional passage rates decreased with advancing plant maturity for the low-N-fertilized grass silage but increased for the high-N-fertilized grass silage. Fractional rumen passage rates were higher for the high compared with the low level of $\mathrm{N}$ fertilization. Passage kinetics of $\delta^{13} \mathrm{C}$-labeled fiber differed from those of the external marker $\mathrm{Cr}$ NDF and fiber-bound $\delta^{15} \mathrm{~N}$. Both sampling sites (i.e., feces vs. omasum) provided similar estimates of rumen fractional passage rate.

\section{ACKNOWLEDGMENTS}

We acknowledge the Dutch Commodity Board of Feedstuffs (The Hague, the Netherlands) for financial support of this research project. We thank T. Parenti and T. Muchemwa at Wageningen University (Wageningen, the Netherlands), as well as A. Coutinho do Rêgo of Universidade Estadual Paulista (Jaboticabal, Brazil) for assistance in sample collection. We thank our laboratory and technical staff, in particular J.-M. Muijlaert and M. J. H. Breuer (both from Wageningen University, Wageningen, the Netherlands) for assistance with stable isotope analyses. 


\section{REFERENCES}

Abrahamse, P. A., J. Dijkstra, B. Vlaeminck, and S. Tamminga. 2008a. Frequent allocation of rotationally grazed dairy cows changes grazing behavior and improves productivity. J. Dairy Sci. 91:2033-2045.

Abrahamse, P. A., B. Vlaeminck, S. Tamminga, and J. Dijkstra. 2008b. The effect of silage and concentrate type on intake behavior, rumen function, and milk production in dairy cows in early and late lactation. J. Dairy Sci. 91:4778-4792.

Bayat, A. R., M. Rinne, K. Kuoppala, S. Ahvenjärvi, and P. Huhtanen 2011. Ruminal large and small particle kinetics in dairy cows fed primary growth and regrowth grass silages harvested at two stages of growth. Anim. Feed Sci. Technol. 165:51-60.

Bayat, A. R., M. Rinne, K. Kuoppala, S. Ahvenjärvi, A. Vanhatalo, and P. Huhtanen. 2010. Ruminal large and small particle kinetics in dairy cows fed red clover and grass silages harvested at two stages of growth. Anim. Feed Sci. Technol. 155:86-98.

Bibby, J., and H. Toutenburg. 1977. Prediction and Improved Estimation in Linear Models. Wiley and Sons, London, UK.

Bosch, M. W., and M. Bruining. 1995. Passage rate and total clearance rate from the rumen of cows fed on grass silages differing in cellwall content. Br. J. Nutr. 73:41-49.

Bosch, M. W., S. C. W. Lammers-Wienhoven, G. A. Bangma, H. Boer, and P. W. M. van Adrichem. 1992a. Influence of stage of maturity of grass silages on digestion processes in dairy cows. 2. Rumen contents, passage rates, distribution of rumen and faecal particles and mastication activity. Livest. Prod. Sci. 32:265-281.

Bosch, M. W., S. Tamminga, G. Post, C. P. Leffering, and J. M. Muylaert. 1992b. Influence of stage of maturity of grass silages on digestion processes in dairy cows. 1. Composition, nylon bag degradation rates, fermentation characteristics, digestibility and intake. Livest. Prod. Sci. 32:245-264.

Cherney, D. J., D. R. Mertens, and J. E. Moore. 1991. Fluid and particulate retention times in sheep as influenced by intake level and forage morphological composition. J. Anim. Sci. 69:413-422.

De Boever, J. L., D. L. De Brabander, A. M. De Smet, J. M. Vanacker, and C. V. Boucque. 1993a. Evaluation of physical structure. 2. Maize silage. J. Dairy Sci. 76:1624-1634.

De Boever, J. L., A. De Smet, D. L. De Brabander, and C. V. Boucque. 1993b. Evaluation of physical structure. 1. Grass silage. J. Dairy Sci. $76: 140-153$.

Dhanoa, M. S., R. C. Siddons, J. France, and D. L. Gale. 1985. A multicompartmental model to describe marker excretion patterns in ruminant faeces. Br. J. Nutr. 53:663-671.

Dijkstra, J., E. Kebreab, J. A. N. Mills, W. F. Pellikaan, S. López, A. Bannink, and J. France. 2007. Predicting the profile of nutrients available for absorption: From nutrient requirement to animal response and environmental impact. Animal 1:99-111.

Faichney, G. J. 1975. The use of markers to partition digestion within the gastro-intestinal tract of ruminants. Pages 227-291 in Digestion and Metabolism in the Ruminant. I. W. McDonald and A. C. I. Warner, ed. University of New England Publishing Unit, Armidale, Australia.

Firkins, J. L., M. S. Allen, B. S. Oldick, and N. R. St-Pierre. 1998. Modeling ruminal digestibility of carbohydrates and microbial protein flow to the duodenum. J. Dairy Sci. 81:3350-3369.

Gasa, J., K. Holtenius, J. D. Sutton, M. S. Dhanoa, and D. J. Napper. 1991. Rumen fill and digesta kinetics in lactating Friesian cows given two levels of concentrates with two types of grass silage ad lib. Br. J. Nutr. 66:381-398.

Gorissen, A., P. J. Kuikman, J. H. van Ginkel, H. Beek, and A. G. Jansen. 1996. ESPAS - An advanced phytotron for measuring carbon dynamics in a whole plant-soil system. Plant Soil 179:81-87.

Harris, S. L., E. R. Thom, and D. A. Clark. 1996. Effect of high rates of nitrogen fertilizer on perennial ryegrass growth and morphology in grazed dairy pasture in northern New Zealand. N. Z. J. Agric. Res. 39:159-169.

Huhtanen, P., P. G. Brotz, and L. D. Satter. 1997. Omasal sampling technique for assessing fermentative digestion in the forestomach of dairy cows. J. Anim. Sci. 75:1380-1392.
Huhtanen, P., and A. N. Hristov. 2001. Estimating passage kinetics using fiber-bound ${ }^{15} \mathrm{~N}$ as an internal marker. Anim. Feed Sci. Technol. 94:29-41.

Jalali, A. R., P. Nørgaard, M. R. Weisbjerg, and E. Nadeau. 2012. Effect of stage of maturity of grass at harvest on intake, chewing activity and distribution of particle size in faeces from pregnant ewes. Animal 6:1774-1783.

Kebreab, E., J. Dijkstra, A. Bannink, and J. France. 2009. Recent advances in modeling nutrient utilization in ruminants. J. Anim. Sci. 87(E. Suppl.):E111-E122.

Khan, N. A., J. W. Cone, V. Fievez, and W. H. Hendriks. 2011. Stability of fatty acids during wilting of perennial ryegrass (Lolium perenne L.): Effect of bruising and environmental conditions. J. Sci. Food Agric. 91:1659-1665.

Krämer, M., P. Nørgaard, P. Lund, and M. R. Weisbjerg. 2013. Particle size alterations of feedstuffs during in situ neutral detergent fiber incubation. J. Dairy Sci. 96:4601-4614.

Kuoppala, K., S. Ahvenjärvi, M. Rinne, and A. Vanhatalo. 2009. Effects of feeding grass or red clover silage cut at two maturity stages in dairy cows. 2. Dry matter intake and cell wall digestion kinetics. J. Dairy Sci. 92:5634-5644.

Lamb, J. B., D. C. Adams, T. J. Klopfenstein, R. J. Grant, P. L. Sims, L. M. White, and S. S. Waller. 2002. Intake and digestive kinetics of leaf and stem fractions. J. Range Manage. 55:57-64.

Lund, P., M. R. Weisbjerg, and T. Hvelplund. 2006. Passage kinetics of fiber in dairy cows obtained from duodenal and faecal ytterbium excretion. Effect of forage type. Anim. Feed Sci. Technol. 128:229-252.

Mackle, T. R., C. R. Parr, and A. M. Bryant. 1996. Nitrogen fertiliser effects on milk yield and composition, pasture intake, nitrogen and energy partitioning, and rumen fermentation parameters of dairy cows in early lactation. N.Z. J. Agric. Res. 39:341-356.

Mambrini, M. S., and J. L. Peyraud. 1994. Mean retention time in digestive tract and digestion of fresh perennial ryegrass by lactating dairy cows: Influence of grass maturity and comparison with a maize silage diet. Reprod. Nutr. Dev. 34:9-23.

NRC. 2001. Nutrient Requirements of Dairy Cattle. 7th rev. ed. National Academies Press, Washington, DC.

Owens, D., M. McGee, and T. Boland. 2008a. Effect of grass regrowth interval on intake, rumen digestion and nutrient flow to the omasum in beef cattle. Anim. Feed Sci. Technol. 146:21-41.

Owens, D., M. McGee, and T. Boland. 2008b. Intake, rumen fermentation, degradability and digestion kinetics in beef cattle offered autumn grass herbage differing in regrowth interval. Grass Forage Sci. 63:369-379.

Owens, F. N., and C. F. Hanson. 1992. External and internal markers for appraising site and extent of digestion in ruminants. J. Dairy Sci. 75:2605-2617

Pellikaan, W. F., M. W. A. Verstegen, S. Tamminga, J. Dijkstra, and W. H. Hendriks. 2013. $\delta^{13} \mathrm{C}$ as a marker to study digesta passage kinetics in ruminants; a combined in vivo and in vitro study. Animal $7: 754-767$.

Peyraud, J. L., and L. Astigarraga. 1998. Review of the effect of nitrogen fertilization on the chemical composition, intake, digestion and nutritive value of fresh herbage: Consequences on animal nutrition and N balance. Anim. Feed Sci. Technol. 72:235-259.

Peyraud, J. L., L. Astigarraga, and P. Faverdin. 1997. Digestion of fresh perennial ryegrass fertilized at two levels of nitrogen by lactating dairy cows. Anim. Feed Sci. Technol. 64:155-171.

Poppi, D. P., D. J. Minson, and J. H. Ternouth. 1981. Studies of cattle and sheep eating leaf and stem fractions of grasses. III. The retention time in the rumen of large feed particles. Aust. J. Agric. Res. 32:123-137.

Rinne, M., P. Huhtanen, and S. Jaakkola. 1997a. Grass maturity effects on cattle fed silage-based diets. 2. Cell wall digestibility, digestion and passage kinetics. Anim. Feed Sci. Technol. 67:19-35.

Rinne, M., P. Huhtanen, and S. Jaakkola. 2002. Digestive processes of dairy cows fed silages harvested at four stages of grass maturity. J. Anim. Sci. 80:1986-1998.

Rinne, M., S. Jaakkola, and P. Huhtanen. 1997b. Grass maturity effects on cattle fed silage-based diets. 1. Organic matter digestion, 
rumen fermentation and nitrogen utilization. Anim. Feed Sci. Technol. 67:1-17.

Robinson, P. H., J. G. Fadel, and S. Tamminga. 1986. Evaluation of mathematical models to describe neutral detergent residue in terms of its susceptibility to degradation in the rumen. Anim. Feed Sci. Technol. 15:249-271.

Romney, D. L., and M. Gill. 2000. Intake of forages. Pages 43-62 in Forage Evaluation in Ruminant Nutrition. D. I. Givens, E. Owen, R. F. E. Axford and H. M. Omed, ed. CAB International, Wallingford, UK.

Smith, L. W. 1989. A review of the use of intrinsically ${ }^{14} \mathrm{C}$ and rare earth-labeled neutral detergent fiber to estimate particle digestion and passage. J. Anim. Sci. 67:2123-2128.

Südekum, K. H., W. Ziggers, N. Roos, H. Sick, S. Tamminga, and M. Stangassinger. 1995. Estimating the passage of digesta in steers and wethers using the ration of ${ }^{13} \mathrm{C}$ to ${ }^{12} \mathrm{C}$ and titanium(IV)-oxide. Isotopes Environ. Health Stud. 31:219-227.

Sutherland, T. M. 1988. Particle separation in the forestomachs of sheep. Pages 43-73 in Aspects of Digestive Physiology in Ruminants. A. Dobson, ed. Cornell University Press, Ithaca, NY.

Svejcar, T. J., M. B. Judkins, and T. W. Boutton. 1993. Technical note: Labeling of forages with ${ }^{13} \mathrm{C}$ for nutrition and metabolism studies. J. Anim. Sci. 71:1320-1325.

Tahir, M. N., P. Lund, and M. Hetta. 2013. The effects of and interactions between the maturity of grass silage and concentrate starch source when offered as total mixed rations on the performance of dairy cows. Animal 7:580-590.

Tamminga, S., P. H. Robinson, M. Vogt, and H. Boer. 1989. Rumen ingesta kinetics of cell wall components in dairy cows. Anim. Feed Sci. Technol. 25:89-98

Tas, B. M., H. Z. Taweel, H. J. Smit, A. Elgersma, J. Dijkstra, and S. Tamminga. 2006. Rumen degradation characteristics of perennial ryegrass cultivars during the growing season. Anim. Feed Sci. Technol. 131:102-119.

Thomas, C. 2004. Feed into Milk: An Advisory Manual. Nottingham University Press, Nottingham, UK.

Udén, P., P. E. Colucci, and P. J. Van Soest. 1980. Investigation of chromium, cerium and cobalt as markers in digesta. Rate of passage studies. J. Sci. Food Agric. 31:625-632.

Ulyatt, M. J. 1983. Plant fibre and regulation of digestion in the ruminant. Pages 103-107 in Fibre in Human and Animal Nutrition.
G. Wallace and L. Bell, ed. The Royal Society of New Zealand, Wellington, New Zealand.

Valk, H., I. E. Leusink-Kappers, and S. Tamminga. 1996. In sacco degradation characteristics of organic matter, neutral detergent fibre and crude protein of fresh grass fertilized with different amounts of nitrogen. Anim. Feed Sci. Technol. 63:63-87.

van Duinkerken, G., M. C. Blok, A. Bannink, J. W. Cone, J. Dijkstra, A. M. van Vuuren, and S. Tamminga. 2011. Update of the Dutch protein evaluation system for ruminants: The DVE/OEB 2010 system. J. Agric. Sci. 149:351-367.

van Vliet, P. C. J., J. W. Reijs, J. Bloem, J. Dijkstra, and R. G. M. de Goede. 2007. Effects of cow diet on the microbial community and organic matter and nitrogen content of feces. J. Dairy Sci. 90:5146-5158.

van Vuuren, A. M., K. Bergsma, F. Frol-Kramer, and J. A. C. van Beers. 1989. Effects of addition of cell wall degrading enzymes on the chemical composition and the in sacco degradation of grass silage. Grass Forage Sci. 44:223-230.

van Vuuren, A. M., S. Tamminga, and R. S. Ketelaar. 1991. In sacco degradation of organic matter and crude protein of fresh grass (Lolium perenne) in the rumen of grazing dairy cows. J. Agric. Sci. 116:429-436.

Volden, H. 2011. NorFor-The Nordic Feed Evaluation System. EAAP publication No. 130. Wageningen Academic Publishers, Wageningen, the Netherlands.

Warner, D., J. Dijkstra, W. H. Hendriks, and W. F. Pellikaan. 2013a. Passage kinetics of ${ }^{13} \mathrm{C}$-labeled corn silage components through the gastrointestinal tract of dairy cows. J. Dairy Sci. 96:5844-5858. http://dx.doi.org/10.3168/jds.2013-6694.

Warner, D., J. Dijkstra, W. H. Hendriks, and W. F. Pellikaan. 2013b. Passage kinetics of concentrates in dairy cows measured with carbon stable isotopes. Animal http://dx.doi.org/10.1017/ S1751731113001584.

Wilman, D., D. Droushiotis, M. N. Mzamane, and J. S. Shim. 1977. The effect of interval between harvests and nitrogen application on initiation, emergence and longevity of leaves, longevity of tillers and dimensions and weights of leaves and 'stems' in Lolium. J. Agric. Sci. 89:65-79.

Wilman, D., and P. J. Pearse. 1984. Effects of applied nitrogen on grass yield, nitrogen content, tillers and leaves in field swards. J. Agric. Sci. 103:201-211. 